\title{
FUNCTIONAL CLASSIFICATION OF CHILDREN WITH CEREBRAL PALSY IN KRAPINA-ZAGORJE COUNTY
}

\author{
Sunčica Martinec ${ }^{1,2}$, Gordana Cesarec ${ }^{1,2}$, Ana Marija Tomečak Krilić ${ }^{1}$, \\ Tomislav Radošević ${ }^{1}, \check{Z Z a r k o ~ B a k r a n ~}^{1,2}$ and Vlatka Mejaški Bošnjak ${ }^{3}$ \\ ${ }^{1}$ Krapinske Toplice Special Hospital for Medical Rehabilitation, \\ Department of Physical and Rehabilitation Medicine, Krapinske Toplice, Croatia; \\ ${ }_{2}^{2}$ Josip Juraj Strossmayer University of Osijek, School of Medicine, Osijek, Croatia; \\ ${ }^{3}$ Department of Neuropediatrics, Zagreb Children's Hospital, School of Medicine, University of Zagreb, \\ Zagreb, Croatia
}

\begin{abstract}
SUMMARY - The aim was to study functional abilities and to create functional classification of children with cerebral palsy $(\mathrm{CP})$ in Krapina-Zagorje County, based on the classification of gross and fine motor skills and associated impairments. Classification was performed according to the SCPE (Surveillance of Cerebral Palsy in Europe) criteria. We used standardized and complementary functional classification systems for cerebral palsy to create a functional profile. Research included 44 children with $\mathrm{CP}$ in the age range of 4 to 18 years. The results showed that the majority of children had bilateral spastic CP (63.6\%), followed by unilateral spastic (22.7\%) while the representation of dyskinetic $\mathrm{CP}$ was $9.09 \%$ and ataxic $\mathrm{CP} 4.55 \%$. Based on the classification of gross and fine motor skills, $43.2 \%$ of children had the ability to walk, $11 \%$ of children could walk with assistive mobility devices, while $45.4 \%$ of children had a low functional level. The study also analyzed the associated impairments where higher classification score of motor impairment correlated with the severity of impairment. The results showed that children with dyskinetic $\mathrm{CP}$ and severe motor impairment could have mild cognitive impairment. We systematically present the neuropsychological and functional profile according to the $\mathrm{CP}$ type.
\end{abstract}

Key words: Functional classification; Cerebral palsy; Associated impairments; Functional profile

\section{Introduction}

Cerebral palsy $(\mathrm{CP})$ represents a clinical diagnosis based on perinatal history data, clinical features, patient medical history and course of the disease, and is defined as a neuromotor disorder of posture and movement, muscle tone and reflexes from infant age ${ }^{1,2}$. Along with motor impairments, children with $\mathrm{CP}$ have other associated neurodevelopmental impairments such as vision and hearing impairments, epilepsy, intellectual impairments, motor speech disorder,

Correspondence to: Sunčica Martinec, $M D, P h D$, Krapinske Toplice Special Hospital for Medical Rehabilitation, Gajeva 2, HR-49217 Krapinske Toplice, Croatia

E-mail: suncica.martinec@sbkt.hr

Received September 10, 2019, accepted October 3, 2019 and communication limitations ${ }^{2,3}$. The European project entitled Surveillance of Cerebral Palsy in Europe (SCPE) recognizes a simplified classification of $\mathrm{CP}$ based on neurological symptoms (spastic, dyskinetic, and ataxic types $)^{1}$. According to data of the Croatian SCPE register, Center 28 (C28 RCP-HR Register of Cerebral Palsy of Croatia), the mean CP prevalence of $2.19 \%$ was recorded ${ }^{4}$. The project, through the shared database, also registers associated impairments and introduces functional classification of CP. Therefore, through our research, general and specific goals were formed whilst being guided by SCPE recommendations. The goal was to form functional profile of children with CP in Krapina-Zagorje County analyzing all types of CP. Likewise, one of the specific goals of the study was comparison of motor and cognitive 
functions between children with spastic $\mathrm{CP}$ and those with dyskinetic type. Regarding motor functioning, the SCPE recommends a classification system for gross motor skills (Gross Motor Function Classification System, GMFCS) and fine motor skills (Bimanual Fine Motor Function, BFMF) ${ }^{5}$. Research has shown GMFCS to be a good predictor of mobility skills $^{6}$. On collecting information on and evaluation of associated impairments in children with $\mathrm{CP}$, four different types of impairments are recommended to consider: intellectual impairments, visual and hearing impairments, and epilepsy ${ }^{7}$. Taking into account different causes and locations of brain damage, it is expected that children with $\mathrm{CP}$ will develop a wide spectrum of cognitive impairments. As part of the SCPE network project (SCPE-NET), a task force was formed to monitor intellectual disability in order to create a $\mathrm{Eu}-$ ropean database ${ }^{8}$. It seems that there is a lack of knowledge about the effects of $\mathrm{CP}$ on motor, intellectual, and neurophysiological functions in children'. Sensorimotor and perceptive problems in individuals with $\mathrm{CP}$ can cause limitations in communication functions and motor speech. Therefore, classification systems have been developed for communication functions (Communication Function Classification System, CFCS) and speech abilities (Viking Speech Scale, VSS). The use of compatible classification systems contributes to better understanding of the functioning and activities of individuals with $\mathrm{CP}$ in their everyday lives, in accordance with the International Classification of Functioning, Disability and Health $(\mathrm{ICF})^{10}$.

\section{Subjects and Methods}

The research included children with $\mathrm{CP}$, classified according to SCPE recommendations, at all levels of motor functioning according to the GMFCS system, age range 4-18 years. The research was conducted in the Krapina-Zagorje County, Croatia. The children were monitored within the National C28 RCP-HR Register of Cerebral Palsy in Croatia and data were collected through the regional County register. In total, 44 children with CP were included and evaluated, through medical examination and available medical documentation, by a physician, physical and rehabilitation medicine specialist, acting as the County Register coordinator. General information was collected on each participant (name, date of birth, sex), course of pregnancy and birth data, and specific information on $\mathrm{CP}$ classification (CP type and subtype) and associated impairments. The following variables were defined as instruments for evaluation and classification: classification of $\mathrm{CP}$ type, classification of gross and fine motor function, and classification of associated impairments (visual, hearing, speech, communication, intellectual disorders, and epilepsy). Classification of all variables was done according to the SCPE criteria ${ }^{4}$. Cerebral palsy was classified into three types: spastic (with bilateral and unilateral subtypes), dyskinetic (with dystonic and choreoathetotic subtype), and ataxic CP. The GMFCS system was used for classification of gross motor function, and BFMF system for classification of fine motor skills ${ }^{11}$. Both systems are correlated and classify motor skills through five levels (I$\mathrm{V})^{12,13}$. Visual impairment according to SCPE recommendations was classified in three categories: none, mild, and severe (blindness or no useful vision, after correction, on the better eye, the level of visual impairment is $>6 / 60 /$ Snellen scale) or $<0.1$ (decimal scale) on both eyes). Hearing impairment was categorized in three levels: none, mild, and severe (severe or profound hearing loss, before correction, on the better ear, the level of hearing loss is $>70 \mathrm{db}$ on both ears). Intellectual impairment was classified in three intelligence quotient (IQ) categories according to the SCP: IQ $\geq 85$, normal intellect, normal schooling; IQ 50-84, mild to moderate intellectual impairment (reading, writing, calculating, but modified school curriculum); and IQ $<50$, severe intellectual impairment (without ability to read, write or calculate). Speech production was evaluated through the VSS across 4 levels. The scale was validated through research in the project of the European register for CP (SCPE-NET) and was assessed as a reliable tool to describe speech capabilities; it can be used in clinical monitoring and collecting information through the CP register ${ }^{14}$. VSS is best suited for the purpose of epidemiological monitoring $^{15}$. Communication skills were evaluated through the CFCS scale at 5 levels. The scale showed good reliability in estimating everyday communication performance and was developed to form functional profile of people with $\mathrm{CP}^{10}$. When assessing the CFCS level, all forms of communication are taken into consideration including speech, gestures, behavior, facial expressions, and augmentative and alternative communication $(\mathrm{AAC})^{16}$. The scale is used in research, as well as in 
regular clinical setting, and complements the use of $\mathrm{VSS}^{17,18}$. Epilepsy was defined as two or more unprovoked seizures, excluding febrile or neonatal seizures. For each participant, a database was formed based on the CP type, GMFCS and BFMF classification, and associated impairment classification. The research was approved by the Ethics Committee of the Osijek Fac-

Table 1. Cerebral palsy types and subtypes according to SCPE classification

\begin{tabular}{|l|l|l|}
\hline CP type & Subtype & $\mathrm{n}(\%)$ \\
\hline Spastic & Bilateral & $28(63.6)$ \\
& Unilateral & $10(22.7)$ \\
\hline Dyskinetic & Dystonic & $4(9.09)$ \\
& Choreoathetotic & 0 \\
\hline Ataxic & & $2(4.55)$ \\
\hline Total & & $44(100)$ \\
\hline
\end{tabular}

$C P=$ cerebral palsy; SCPE = Surveillance of Cerebral

Palsy in Europe; $n=$ number of patients ulty of Medicine and Krapinske Toplice Special Hospital for Medical Rehabilitation.

Data were analyzed using the MS Excel, 2010 with Data Analysis Toolkit Package. Descriptive statistics were calculated for participant characteristics. The $\mathrm{t}$ test was used to determine statistical significance of differences between the groups.

\section{Results}

A total of 44 children ( 25 boys and 19 girls), age range $4-18$ years, participated in the research. Analysis of CP type classification showed spastic CP type in 38 (86.3\%) patients, including bilateral spastic CP in 28 (63.6\%) and unilateral spastic CP in ten (22.7\%) patients. Dyskinetic CP type was recorded in four (9.09\%) and ataxic CP type in two (4.55\%) patients (Table 1). None of the study children had choreoathetotic CP subtype.

Table 2 shows results of the gross and fine motor function classification. At the GMFCS levels I-II,

Table 2. Functional classification of motor impairment: Gross Motor Function Classification System and Bimanual Fine Motor Function

\begin{tabular}{|l|l|l|l|l|l|l|}
\hline GMFCS level & I & II & III & IV & V & Total \\
\hline $\mathrm{n}(\%)$ & $8(18.2)$ & $11(25)$ & $5(11.4)$ & $11(25)$ & $9(20.4)$ & $44(100)$ \\
\hline BFMF level & I & II & III & IV & V & Total \\
\hline $\mathrm{n}(\%)$ & $7(15.9)$ & $17(38.6)$ & $5(11.4)$ & $10(22.7)$ & $5(11.4)$ & $44(100)$ \\
\hline
\end{tabular}

GMFCS $=$ Gross Motor Function Classification System; BFMF = Bimanual Fine Motor Function; $\mathrm{n}=$ number of patients

Table 3. Classification of associated impairments: visual and hearing impairments, speech, communication, intellectual impairment and epilepsy

\begin{tabular}{|c|c|c|c|c|c|c|}
\hline & $\begin{array}{l}\text { Normal } \\
\mathrm{n}(\%)\end{array}$ & $\begin{array}{l}\text { Mild } \\
\mathrm{n}(\%)\end{array}$ & \multicolumn{3}{|l|}{$\begin{array}{l}\text { Severe } \\
\mathrm{n}(\%)\end{array}$} & Total \\
\hline Vision & $20(45.5)$ & $18(40.9)$ & \multicolumn{3}{|l|}{$4(9.09)$} & $42+2 \mathrm{NA}$ \\
\hline Hearing & $37(84.1)$ & $1(2.27)$ & \multicolumn{3}{|l|}{0} & $38+6 \mathrm{NA}$ \\
\hline & Viking I & Viking II & Viking III & \multicolumn{2}{|l|}{ Viking IV } & Total \\
\hline Speech & $23(52.3)$ & $5(11.4)$ & $7(15.9)$ & \multicolumn{2}{|l|}{$9(20.4)$} & 44 \\
\hline & CFCS I & CFCS II & CFCS III & CFCS IV & CFCS V & Total \\
\hline \multirow[t]{2}{*}{ Communication } & $26(59.1)$ & $1(2.27)$ & $4(9.1)$ & $3(6.8)$ & $10(22.7)$ & 44 \\
\hline & Normal & Mild to moderate & \multicolumn{3}{|l|}{ Severe } & Total \\
\hline \multirow[t]{2}{*}{$\begin{array}{l}\text { Intellectual } \\
\text { impairment }\end{array}$} & $21(47.7)$ & $12(27.3)$ & & $43+1 \mathrm{NA}$ \\
\hline & No & Yes & \multicolumn{3}{|l|}{$10(22.7)$} & Total \\
\hline Epilepsy & $31(70.5)$ & $13(29.5)$ & & & & 44 \\
\hline
\end{tabular}

CFCS = Communication Function Classification System; Viking = Viking Speech Scale; NA = not available; $n=$ number of patients 
Table 4. Functional classification of motor impairment (GMFCS and BFMF) and intellectual impairment in the group with spastic cerebral palsy

\begin{tabular}{|l|l|l|l|l|l|l|}
\hline GMFCS level & I & II & III & IV & V & Total \\
\hline $\mathrm{n}(\%)$ & $8(21.1)$ & $10(26.3)$ & $3(7.9)$ & $10(26.3)$ & $7(18.4)$ & 38 \\
\hline BFMF & I & II & III & IV & V & Total \\
\hline $\mathrm{n}(\%)$ & $6(15.8)$ & $16(42.1)$ & $3(7.9)$ & $9(23.7)$ & $4(10.5)$ & 38 \\
\hline Intellectual impairment & Normal & Mild/moderate & Severe & & & Total \\
\hline $\mathrm{n}(\%)$ & $19(50)$ & $9(23.7)$ & $9(23.7)$ & & & $37+1 \mathrm{NA}$ \\
\hline
\end{tabular}

GMFCS = Gross Motor Function Classification System; BFMF = Bimanual Fine Motor Function; NA = not available; $\mathrm{n}=$ number of patients

Table 5. Functional classification of motor impairment (GMFCS and BFMF) and intellectual impairment in the group with dyskinetic cerebral palsy

\begin{tabular}{|l|l|l|l|l|l|l|}
\hline GMFCS level & I & II & III & IV & V & Total \\
\hline $\mathrm{n}$ & & & 1 & 1 & 2 & 4 \\
\hline BFMF & I & II & III & IV & V & \\
\hline $\mathrm{n}$ & & & 2 & 1 & 1 & 4 \\
\hline Intellectual impairment & Normal & Mild/moderate & Severe & & & \\
\hline $\mathrm{n}$ & 2 & 1 & 1 & & & 4 \\
\hline
\end{tabular}

GMFCS = Gross Motor Function Classification System; BFMF = Bimanual Fine Motor Function; $\mathrm{n}=$ number of patients

which assume the ability to walk, were $43.2 \%$ of participants, with the help of assistive mobility devices; $11.4 \%$ of children were mobile (GMFCS level III), whereas $45.4 \%$ of children had a low functional level, being transported in a wheelchair (GMFCS IV-V). Functional assessment of fine motor skills showed similar results. Of the total number of participants, $54.5 \%$ were classified as level I-II, $11.4 \%$ as level III, and $34.1 \%$ as level IV-V. Classification and assessment according to the levels of associated impairments are shown in Table 3. Normal vision was found in $45.5 \%$, mild vision impairment in $40.9 \%$ and severe vision impairment in $9.09 \%$ of children. Thirty-seven (84.1\%) patients had no hearing impairment, while one patient had mild hearing impairment. Severe hearing impairment was not recorded. On speech assessment on the VSS, 23 children were classified as level I, five as level II, seven as level III, and nine level IV (no understandable speech). Classification of everyday communication was analyzed by CFCS scale through 5 levels: 26 (59.1\%) children had effective communication (CFCS I), one child was classified as CFCS level II, four children were on the CFCS level III, whilst 13 children were inconsistent sender and/or receiver or seldom ef- fective sender and receiver with familiar partners (levels IV and V). Cognitive development was normal in $21(47.4 \%)$ children, $12(27.3 \%)$ children had mild to moderate delay, while ten (22.7\%) children were diagnosed with severe intellectual impairment. Epilepsy was recorded in $29.5 \%$ of patients.

In order to further analyze motor and cognitive functions in children with spastic and dyskinetic $\mathrm{CP}$, two participant groups were formed for these $\mathrm{CP}$ types. Tables 4 and 5 show their results. There were 38 children in the spastic type group (Table 4) and four children in the dyskinetic type group (Table 5). Children in the dyskinetic CP group, classified on GMFCS classification at the levels III-V, had a lower level of motor function. In the spastic $\mathrm{CP}$ group, functional classification of motor impairment included all levels (GMFCS I-V). Moderate motor impairment, GMFCS III, was recorded in $1 / 4$ children with dyskinetic $\mathrm{CP}$ and 3/38 children with spastic CP. Severe motor impairment, GMFCS levels IV-V, was recorded in 3/4 children with dyskinetic $\mathrm{CP}$ and 17/38 children with spastic CP. Severe cognitive impairment was found in 1/4 children with dyskinetic CP and 9/38 children with spastic CP. Comparison of gross and fine motor 


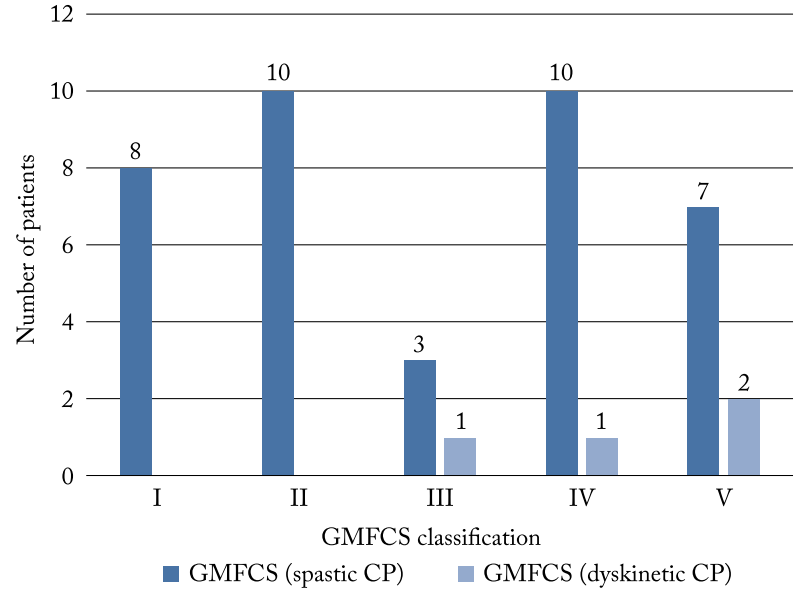

GMFCS = Gross Motor Function Classification System; $\mathrm{CP}=$ cerebral palsy

Fig. 1. Comparison of GMFCS classification level between the groups with spastic and dyskinetic cerebral palsy.

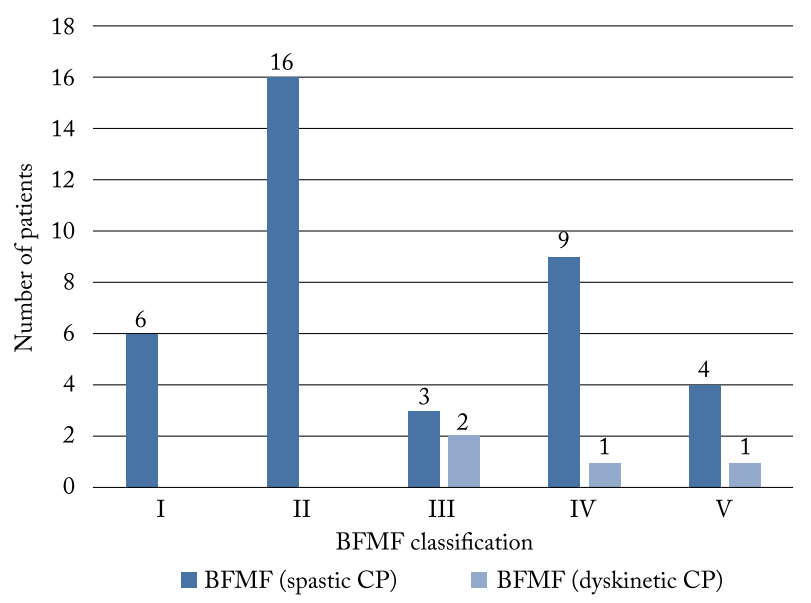

BFMF = Bimanual Fine Motor Function; $\mathrm{CP}=$ cerebral palsy

Fig. 2. Comparison of BFMF classification level between the groups with spastic and dyskinetic cerebral palsy.

function classification (GMFCS and BFMF) between spastic and dyskinetic $\mathrm{CP}$ is illustrated in Figures 1 and 2 .

Considering that children in the group with dyskinetic CP had more severe motor impairment (GMFCS III-V) compared to the group with spastic CP (GMFCS I-V), the results of children classified at higher levels of motor functioning, GMFCS III-V and BFMF II-V (four children with dyskinetic CP and 19 children with spastic $\mathrm{CP}$ ) were taken in order

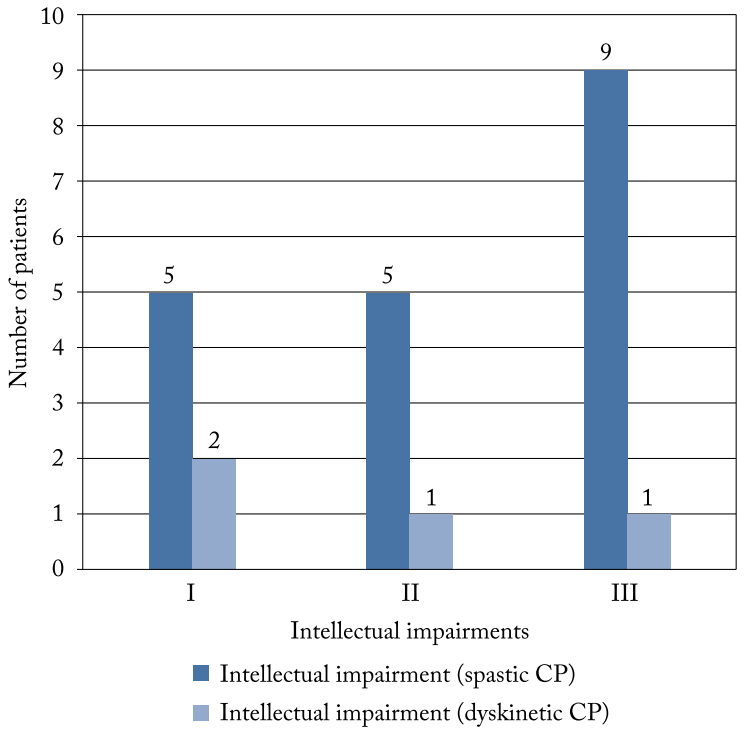

Fig. 3. Comparison of intellectual impairments between children with spastic and dyskinetic cerebral palsy $(C P)$ : I - normal, II - mild/moderate, III - severe.

to analyze the relationship of cognitive and motor impairment between these two groups. Figure 3 shows the range of their intellectual impairments.

\section{Discussion}

Our study included 44 children with CP. We used reliable, compatible classification systems for evaluation of motor, cognitive, communication and speech functioning. The most common type of $\mathrm{CP}$ in our study was bilateral spastic $\mathrm{CP}$, followed by unilateral spastic $\mathrm{CP}$, which is in accordance with data in the Croatian CP register ${ }^{4}$. The prevalence of dyskinetic and ataxic $\mathrm{CP}$ in our research was similar to the result distribution reported in the European register database research ${ }^{1}$. The GMFCS classification system, as an indicator, shows the severity of $\mathrm{CP}^{19}$. In our study, almost half of the participants had severe CP with GMFCS levels IV-V, and needed a wheelchair for mobility. Similar results have been reported by Glinac et $a l .^{20}$. Children with this type of CP manifestation have a low level of motor functioning as they have disorder of posture and movement control, as well as head and body control. Thus, their ability to move independently is severely limited, even with walking mobility devices. Results of the study conducted by Palisano et al. showed the between-level differences to be significant 
for everyday functioning ${ }^{21}$. The GMFCS provides a view of functional abilities and capabilities during childhood in the population of $\mathrm{CP}$ children. It is also a good predictor of mobility skills, and helps clinicians in making decisions and setting goals. The system is compatible with the BFMF and a high correlation between the two has also been proven, indicating that the severity of gross and fine motor functions is related ${ }^{22}$. The difference in classification between these two systems rarely goes over one level, which is in accordance with our study. The participants classified with higher levels of gross motor function (GMFCS IV and V) were also classified at higher levels on the BFMF scale.

Along with motor disorders, the study also analyzed associated impairments. Higher levels of GMF$\mathrm{CS}(\mathrm{V}$ and IV) correlated with the presence of more associated impairments, which additionally influence motor development of a child. Intellectual impairment was present in $50 \%$ of children, of which $22.7 \%$ had severe impairments. The results are in accordance with the systematic review of data presented by Novak et al. ${ }^{23}$. Children with neurodevelopmental disorders have an increased prevalence of visual impairment ${ }^{24}$. In older $\mathrm{CP}$ children, visual impairments also affect their quality of life $\mathrm{e}^{25}$. In our study, 9.09\% of children had severe visual impairment. Mild hearing impairment was recorded in $40.9 \%$ of children, while severe impairment was not recorded. In a study from 2018, the authors report the severity of hearing impairment to correlate with the level of motor and neurological impairment ${ }^{26}$. Analysis of speech production showed that speech was not affected by motor impairments in more than half of the participants, whereas $21 / 44$ children had some level of speech impairment on the VSS (IIIV). The profile of communication functions in children with CP could be estimated by the CFCS, which correlates with GMFCS and BFMF and cognitive function $s^{27}$. In our study population, complete effectiveness in communication was present in $59.1 \%$ of children, whereas $29.5 \%$ of children were classified as inconsistent sender and/or receiver, or seldom as effective sender and receiver of information (CFCS levels IV-V). The usage of both CFCS and GMFCS contributes to the overall aspect of functionality in everyday activities in individuals with $\mathrm{CP}$.

A specific goal of our study was to analyze motor and intellectual impairments in children with spastic $\mathrm{CP}$ type compared to children with dyskinetic $\mathrm{CP}$ type. The results showed that patients with dyskinetic type of $\mathrm{CP}$ could have mild intellectual impairment despite severe motor impairment (GMFCS/BFMF $\geq 3$ ). The level of classification of gross and fine motor function is a good predictor of motor impairment and need not implicitly predict intellectual impairment. The results of our study showed that severe motor impairment in dyskinetic $\mathrm{CP}$ did not necessarily implicate severe intellectual impairment. The results of cognitive assessment in children with $\mathrm{CP}$ are sometimes a reflection of motor limitations, which is in accordance with a study reporting that cognitive skills can be masked by the severity of motor impairments and lack of movement control, which is especially the case in children with dyskinetic CP who cannot fully follow certain tests due to discrepancies in motor and verbal capabilities $^{28}$. The analysis of functioning in our research encompassed participants at all motor skill classification levels, which could be an advantage when it comes to interpreting and making a conclusion. Overall, the results of our study are consistent with data reported from the European Register of $\mathrm{CP}^{19}$. Classification systems used in this research are valid and compatible. The unique database was formed and functional profile of every individual with $\mathrm{CP}$ in our County was created. The results will help in clinical practice, identifying goals and evaluating intervention procedures. Neuropsychological profiles and characteristics of associated impairments in $\mathrm{CP}$ children from the Krapina-Zagorje County are systematically presented according to the type of $\mathrm{CP}$, as well as their functional skills and functioning levels, which had not been done before. A limitation of the study was the small sample size, however, it was predetermined by the number of children with $\mathrm{CP}$ in the County. Following this research, the plan is to extend the database and functional profile with the Gross Motor Function Measure, which will complete our understanding the functioning of a child with $\mathrm{CP}$.

\section{References}

1. Mejaški Bošnjak V, Đaković I. Europska klasifikacija cerebralne paralize. Paediatr Croat. 2013;57(1):93-7. (in Croatian)

2. Mejaški Bošnjak V. Smjernice Hrvatskog društva za dječju neurologiju za cerebralnu paralizu. Paediatr Croat. 2012;56: 157-63. (in Croatian)

3. Himmelmann K, McManus V, Hagberg G, Uvebrant P, Krageloh-Mann I, Cans C. Dyskinetic cerebral palsy in Europe: 
trends in prevalence and severity. Arch Dis Child. 2009;94 (12):921-6. doi: 10.1136/adc.2008.144014

4. Mejaški Bošnjak V, Đaković I; on behalf of coordinators of the county registers of children with cerebral palsy. Važnost registra djece s cerebralnom paralizom u Hrvatskoj. Simpozij o istraživanju i bolestima mozga, Knjiga sažetaka; Zagreb, 2017; 32-33. (in Croatian)

5. Palisano R, Rosenbaum P, Walter S, Russel D, Wood E, Galuppi B. Development and reliability of a system to classify gross motor function in children with cerebral palsy. Dev Med Child Neurol. 1997;39:214-23.

6. Ohrvall AM, Eliasson AC, Lowing K, Odman P, Odman P. Self-care and mobility skills in children with cerebral palsy, related to their manual ability and gross motor function classifications. Dev Med Child Neurol. 2010;52:1048-55. doi: 10.1111/j.1469-8749.2010.03764.x

7. Cans C, Dolk H, Platt MJ, Colver A, Prasauskiene A, Krageloh-Mann I. Recommendations from the SCPE Collaborative Group for Defining and Classifying Cerebral Palsy. Dev Med Child Neurol. 2007;49:35-8. doi: 10.1111/j.1469-8749. 2007.tb12626.x

8. Van Bakel M, Einarsson I, Arnaud C, Craig S, Michelsen SI, Pildava S, Uldall P, Cans C. Monitoring the prevalence of severe intellectual disability in children across Europe: feasibility of a common database. Dev Med Child Neurol. 2014;56(4): 361-9. doi: 10.1111/dmcn.12281

9. Fennell EB, Dikel TN. Cognitive and neuropsychological functioning in children with cerebral palsy. J Child Neurol. 2001;16(1):58-63. doi: 10.1177/088307380101600110

10. Cooley Hidecker MJ, Paneth N, Rosenbaum P, Kent RD, Lillie J, Eulenberg JB, Chester K Jr, Johnson B, Michalsen L, Evatt $\mathrm{M}$, Taylor K. Developing and validating the Communication Function Classification System for individuals with cerebral palsy. Dev Med Child Neurol. 2011;53(8):704-10. doi: 10.1111/j.1469-8749.2011.03996.x

11. Elvrum AK, Andersen GL, Himmelman K, Beckung E, Orhvall $A M$, Lydersen S, Vik T. Bimanual fine motor function (BFMF) classification in children with cerebral palsy: aspects of construct and content validity. Phys Occup Ther Pediatr. 2016;36(1):1-16. doi: 10.3109/01942638.2014.975314

12. Harvey A, Robin J, Morris ME, Graham HK, Baker R. A systematic review of measures of activity limitation for children with cerebral palsy. Dev Med Child Neurol. 2008;50:190-8. doi: 10.1111/j.1469-8749.2008.02027.x

13. Oeffinger D, Gorton G, Bagley A, Nicholson D, Barnes D, Calmes J, Abel M, Damiano D, Kryscio R, Rogers S, Tylkowski C. Outcome assessments in children with cerebral palsy. Part I: Descriptive characteristic of GMFCS level I to III. Dev Med Child Neurol. 2007;49:172-80. doi: 10.1111/j.1469-8749. 2007.00172.x

14. Pennington L, Virella D, Mjoen T, Andrada MG, Murray J, Colver A, Himmelmann K, Rackauskaite G, Greitane A, Prasauskiene A, Andersen G, De La Cruz J. Development of the Viking Speech Scale to classify the speech of children with cerebral palsy. Res Dev Disabil. 2013;34:3202-10. doi: 10.1016/j.ridd.2013.06.035

15. Virella D, Pennington L, Andrada MG, Greitane A, Prasauskiene A, Rackauskaite G, Himmelmann K, Andersen GL, De$\mathrm{La}-\mathrm{Cruz}$ J. Scales for assessment of communication ability in the surveillance of children with cerebral palsy. SCPE-NET project. [Internet]. Scpenetwork.eu. [cited 2019 Jul 21]. Available from: http://www.scpenetwork.eu/assets/Summaries/SCPE-NETAnnexes-WP4-2012-Pisa-ICPC-presentation.pdf

16. CFCS - Communication Function Classification Systems [Internet]. Cfcs.us. 2011 [cited 2019 Jul 21]. Available from: http://cfcs.us/

17. Cooley Hidecker MJ, Thi Ho N, Dodge N, Hurvitz EA, Slaughter J, Seif Workinger M, Kent RD, Rosenbaum P, Lenski M, Messaros BM, Vanderbeek SB, Deroos S, Paneth N. Inter-relationships of functional status in cerebral palsy: analyzing gross motor function, manual ability and communication function classification system in children. Dev Med Child Neurol. 2012;54:737-42. doi: 10.1111/j.1469-8749.2012.04312.x

18. Virella D, Pennington L, Andersen GL, Andrada MG, Greitane A, Himmelmann K, Prasauskiene A, Rackauskaite G, De La Cruz J, Colver A. Classification systems of communication for use in epidemiological surveillance of children with cerebral palsy. Surveillance of Cerebral Palsy in Europe Network. Dev Med Child Neurol. 2015;58(3):285-91. doi: 10.1111/dmen.12866

19. Kinsner-Ovaskainen A, Lanzoni M, Delobel M, Ehlinger V, Arnaud C, Martin S. Surveillance of Cerebral Palsy in Europe: Development of the JRC-SCPE Central Database and Public Health Indicators. EUR 28935 EN. Publications Office of the European Union. Luxembourg, 2017. ISBN 978-92-7977064-7. doi: 10.2760/342293, JRC109418

20. Glinac A, Matović L, Delalić A, Mešalić L. Quality of life in mothers of children with cerebral palsy. Acta Clin Croat. 2017;56:299-307. doi: 10.20471/acc.2017.56.02.14

21. Palisano RJ, Hanna SE, Rosenbaum PL, Russell DJ, Walter SD, Wood EP, Raina PS, Galuppi BE. Validation of a model of gross motor function for children with cerebral palsy. Phys Ther. 2000;80(10):974-85.

22. Himmelmann K, Beckung E, Hagberg G, Uvebrant P. Gross and fine motor function and accompanying impairments in cerebral palsy. Dev Med Child Neurol. 2006;48:417-23. doi: 10.1017/S0012162206000922

23. Novak I, Hines M, Goldsmith S, Barclay R. Clinical prognostic messages from a systematic review on cerebral palsy. Pediatrics. 2012;130(5):e1285-e1312. doi: 10.1542/peds.2012-0924

24. Williams C, Northstone K, Borwick C, Gainsborough M, Roe J, Howard S, Rogers S, Amos J, Woodhouse JM. How to help children with neurodevelopmental and visual problems: a scoping review. Br J Ophthalmol. 2014;98(1):6-12. doi: 10.1136/ bjophthalmol-2013-304225

25. Alimović S. Visual impairments in children with cerebral palsy. Hrvat Rev Za Rehabil Istraz. 2012;48(1):96-103. 
26. Weir FW, Hatch JL, McRackan TR, Wallace SA, Meyer TA. Hearing loss in pediatric patients with cerebral palsy. Otol Neurotol. 2018;39(1):59-64. doi: 10.1097/MAO.00000000 00001610

27. Himmelmann K, Lindh K, Hidecker MJ. Communication ability in cerebral palsy: a study from the $\mathrm{CP}$ register of western
Sweden. Eur J Paediatr Neurol. 2013;17(6):568-74. doi: 10.1016/j.ejpn.2013.04.005

28. Sigurdardottir S, Eiriksdottir A, Gunnarsdottir E, Meintema M, Arnadottir U, Vik T. Cognitive profile in young Icelandic children with cerebral palsy. Dev Med Child Neurol. 2008; 50(5):357-62. doi: 10.1111/j.1469-8749.2008.02046.x

Sažetak

\section{FUNKCIONALNA KLASIFIKACIJA DJECE S CEREBRALNOM PARALIZOM U KRAPINSKO-ZAGORSKOJ ŽUPANIJI}

\section{S. Martinec, G. Cesarec, A. M. Tomě̌ak Krilić, T. Radošević, Ž. Bakran i V. Mejaški Bošnjak}

Cilj je bio istražiti funkcionalnu klasifikaciju djece s cerebralnom paralizom (CP) u Krapinsko-zagorskoj županiji na osnovi klasifikacije grubih i finih motoričkih funkcija te pridruženih odstupanja. Klasifikacija je provedena sukladno preporukama europskog projekta pod naslovom Surveillance of Cerebral Palsy in Europe. Primijenjeni su standardizirani i međusobno kompatibilni klasifikacijski sustavi s ciljem formiranja funkcionalnog profila. $U$ istraživanju je sudjelovalo 44 djece s $\mathrm{CP} u$ dobi od 4-18 godina. Rezultati su pokazali da je najučestaliji tip CP obostrani spastični (63,6\%), a potom jednostrani spastični tip (22,7\%). Zastupljenost diskinetske CP u našem istraživanju bila je 9,09\%, a ataktične CP 4,55\%. Sukladno klasifikaciji grubih i finih motoričkih funkcija $43,2 \%$ djece je bilo pokretno, uz pomoć pomagala se moglo kretati $11 \%$ djece, dok je nisku funkcionalnu razinu imalo $45,4 \%$ djece. U studiji su također analizirana i pridružena odstupanja, s tim da su viši stupnjevi klasifikacije motoričkih funkcija korelirali s težinom oštećenja. Rezultati su ukazali na to da djeca s diskinetskim tipom $\mathrm{CP}$ i teškim motoričkim oštećenjem mogu imati blaže kognitivno oštećenje. Istraživanjem je sustavno prikazan neuropsihološki profil i karakteristike pridruženih odstupanja u odnosu na tip CP te je formiran funkcionalni profil za svakog bolesnika.

Ključne riječi: Funkcionalna klasifikacija; Cerebralna paraliza; Pridružena odstupanja; Funkcionalni profil 